\title{
Clinical and epidemiological aspects of a hepatitis $E$ outbreak in Bangui, Central African Republic
}

\author{
Alice I Goumba, Xavier Konamna and Narcisse P Komas ${ }^{*}$
}

\begin{abstract}
Background: Outbreaks of hepatitis E frequently occur in tropical developing countries during the rainy season due to overflowing drains, short-circuiting of networks of clean water and use of contaminated water from wells. Hepatitis E virus (HEV) infections are usually accompanied by general symptoms of acute liver disease. This study was conducted to define the clinical and epidemiological aspects of the HEV outbreak that occurred in May 2004 in Bangui.
\end{abstract}

Methods: Blood samples were collected from 411 patients aged 1-87 years, most of whom presented with jaundice, asthenia or signs of uncomplicated malaria, for a transversal study from June 2004 to September 2005. Patients were recruited at 11 health care centres, including two referral hospitals, after they had given informed consent. The diagnosis of HEV was made with a commercial ELISA test to detect IgM and/or IgG antibodies. HEV RNA was amplified by RT-PCR to confirm the presence of the viral genome.

Results: The most frequent clinical signs found were jaundice (93.4\%), vomiting (50.7\%), hepatalgia (47.4\%), hepatomegaly (30.9\%) and asthenia (26.8\%), which are the general clinical signs of hepatic disease. Acute hepatitis E was found in 213 patients (51.8\%) who were positive for HEV IgM antibodies. The IgG anti-HEV seroprevalence during this outbreak was high (79.5\%). The age group 18-34 years was more frequently infected (91.2\%) than those aged 1-17 (78.0\%) or over 34 (64.9\%) ( $\left.p<10^{-6}\right)$. RT-PCR performed on 127 sera from the 213 IgM-HEV-positive patients was amplified, and the presence of the viral genome was found in 65 samples.

Conclusion: Although no specific clinical signs exist for hepatitis E infection, people presenting with jaundice, vomiting, hepatalgia, asthenia, hepatomegaly or distended abdomen with no signs of uncomplicated malaria in tropical developing countries should be sent to a laboratory for testing for hepatitis $\mathrm{E}$.

\section{Background}

Hepatitis E virus (HEV), a small, single-stranded, hepatotropic RNA virus, currently classified in the genus Hepevirus [1], is responsible for enteric non-A non-B hepatitis in humans. Infection with $\mathrm{HEV}$, thought to spread via the faecal-oral route, causes outbreaks that have been linked to waterborne sources in developing countries; sporadic cases have also been seen [2]. Although the potential for zoonotic and cross-species transmission has been demonstrated $[3,4]$, asymptomatic carriers of HEV have been reported, and such cases are potential human reservoirs of the virus [5]. During epidemics, the person-to-person transmission rate appears to be low, although intrafamilial transmission is possible

\footnotetext{
* Correspondence: npkomas@yahoo.fr

Viral Hepatitis Laboratory, Institut Pasteur de Bangui, PO Box 923, Bangui, Central African Republic
}

[6]. The course of the disease is generally self-limiting; however, chronic HEV infection has been reported in immunocompromised patients [7-10]. Reports have indicated an increased risk for disease and as high as 10$20 \%$ case mortality from fulminant hepatitis during the third trimester of pregnancy [11].

Outbreaks of hepatitis E frequently occur in tropical Africa during the rainy season due to overflowing drains, short-circuiting of networks of clean water and use of contaminated water from wells [12-14]. The Central African Republic (CAR), located in tropical Africa, is considered to be an area of high endemicity for the main infectious diseases, including infections with HIV [15], hepatitis B virus and other hepatotropic viruses $[16,17]$, yellow fever [18], malaria [19], tuberculosis [20] and other infections [21-23]. No HEV epidemics were documented in the CAR before 2001, although HEV

\section{Biomed Central}


antibodies were detected in $24 \%$ of young sexually active adults [24]. The first outbreak of this disease in the CAR was reported in 2001 [25,26], and a further outbreak occurred in 2004.

In order to improve the diagnosis of hepatitis $E$ in CAR, the aim of this study was to determine the clinical and epidemiological characteristics of HEV infection during the outbreak in Bangui.

\section{Methods}

\section{Study population}

One month after the beginning of the 2004 outbreak, 411 patients residing in or around Bangui, aged 1-87 years (average age, $27.9 \pm 5.1$ ), were clinically examined by physicians in 11 health care centres, including two national referral hospitals, and completed a questionnaire to provide sociodemographic information, including gender, age and place of residence (district in Bangui). During standard clinical screening, all persons enrolled in the study were also questioned about their history of symptomatic hepatitis. The main criteria for inclusion in the study were gastrointestinal complaints and fever, leading to a clinical diagnosis of malaria with ineffective malaria treatment. Other inclusion criteria were jaundice, anorexia, diarrhoea, nausea or severe asthenia. Individuals should also have had no history of exposure to blood, such as transfusion.

Informed consent was obtained from all patients included in the study. For those under 18, parental consent was obtained. Each participant or parent was informed of the results of the serology. The study was approved by the Medical Committee of the Institut Pasteur in Paris (France) because of, until the third trimester of 2006, the Central African Republic did not have his own Ethics Committee. Before that time, all the research projects at the Institut Pasteur de Bangui (which is related to Institut Pasteur in Paris, France) were submitted to the Ethics Committee of the Institut Pasteur in Paris (France). Once ethical approval was received, administrative authorization was obtained from the Ministry of the Public Health of the Central African Republic.

\section{Clinical observations}

Patients were examined for jaundice, hepatalgia, vomiting, asthenia, fever, arthralgia, abdominal pain, nausea, anorexia, diarrhoea or headache. They were then examined physically for hepatomegaly, distended abdomen, splenomegaly, oedema of lower limbs, encephalopathy or deterioration of general condition. Physicians could also report any clinical observation not listed in the questionnaire.

\section{Specimen collection}

Blood and stool samples were collected from patients who fulfilled the inclusion criteria over 16 months between June 2004 and September 2005.

\section{Biological testing}

A diagnosis of acute hepatitis E was based on serology. IgM and IgG HEV were detected with a commercial ELISA assay (Bioelisa, Biokit, Spain). Amplification of HEV RNA by RT-PCR was performed to confirm a recent HEV infection. Serum samples were also analysed for AST and ALT. Malaria, hepatitis B and C, and yellow fever were ruled out.

\section{Statistical analysis}

Epi-Info Version 2000 (CDC, USA \& WHO, Geneva, Switzerland) software was used to analyse data on prevalence, with $95 \%$ confidence intervals, and the chisquare test was used for the comparison of variables and associations with HEV positivity. Statistical significance was assumed at $p<0.05$.

\section{Results}

The sex ratio was of 1 (1:1) with $50.9 \%$ males (209) and $49.1 \%$ females (202). Serology results showed that more males were infected during the outbreak than females. IgM anti-HEV antibodies, which predominate in the primary immune response and define acute infection, were detected in the sera of 118 men (56.4\%) and 95 women (47.0\%). The observed difference was not significant. However, males had a higher IgG anti-HEV seroprevalence $(85.1 \%)$ than females $(73.8 \%)$, and the risk for infection was clearly higher in males than females (OR 2.04; 95\% CI 1.21-3.45; $p<0.005$ ) during the period of study.

Table 1 shows the distribution of HEV serology (IgM and IgG) according to age. The age group 18-34 years were more frequently IgM-HEV positive than the other age groups $(1-17$ and $>34$ years $)(p<0.001)$.

Amplification by RT-PCR of 127 serum and 25 stool samples positive for IgM-HEV antibody showed that 50 sera and 24 stool samples were positive, indicating that the viral genome was present.

More than $80 \%$ of patients with positive IgM antiHEV antibody had higher ALT (82.1\%) and AST (86.8\%) values than normal.

The clinical features observed in patients positive for IgM-HEV are listed in Table 2. Although no specific symptoms were reported during the outbreak, jaundice

Table 1 Distribution of 411 patients according to serology during the outbreak of hepatitis $E$ in Bangui in 2004

\begin{tabular}{cccc}
\hline Age (years) & IgM positive (\%) & IgG positive (\%) & Total \\
\hline $1-17$ & $28(56.0)$ & $39(78.0)$ & $50(12.2 \%)$ \\
$18-34$ & $126(61.7)$ & $186(91.2)$ & $204(49.6 \%)$ \\
$>34$ & $59(37.6)$ & $102(64.9)$ & $157(38.2 \%)$ \\
Total & $213(51.8 \%)$ & $327(79.5 \%)$ & 411 \\
\hline
\end{tabular}


Table 2 Clinical features in $\mathbf{4 1 1}$ patients clinically examined during the outbreak of hepatitis $E$ in Bangui in 2004

\begin{tabular}{lc}
\hline Clinical characteristics & Positive IgM-HEV $(\mathbf{n}=\mathbf{2 1 3})$ \\
\hline Clinical signs & \\
\hline Jaundice $(n=353)$ & $199(93.4 \%)$ \\
Vomiting $(n=213)$ & $108(50.7 \%)$ \\
Hepatalgia $(n=212)$ & $101(47.4 \%)$ \\
Hepatomegaly $(n=142)$ & $66(30.9 \%)$ \\
Fever $(n=56)$ & $31(14.5 \%)$ \\
Abdominal pain $(n=18)$ & $9(4.2 \%)$ \\
Dark urine $(n=16)$ & $8(3.7 \%)$ \\
Nausea $(n=11)$ & $7(3.3 \%)$ \\
Itching $(n=9)$ & $6(2.8 \%)$ \\
Encephalopathy $(n=10)$ & $5(2.3 \%)$ \\
Myalgia $(n=3)$ & $3(1.4 \%)$ \\
Hemorrhage $(n=6)$ & $1(0.5 \%)$ \\
Discolored stools $(n=4)$ & $1(0.5 \%)$ \\
\hline Clinical symptoms & \\
\hline Asthenia $(n=84)$ & $57(26.8 \%)$ \\
Distended abdomen $(n=64)$ & $31(14.5 \%)$ \\
Epigastralgia $(n=19)$ & $12(5.6 \%)$ \\
Arthralgia $(n=19)$ & $11(5.2 \%)$ \\
Anorexia $(n=10)$ & $8(3.7 \%)$ \\
Limb oedema $(n=25)$ & $7(3.3 \%)$ \\
Headache $(n=10)$ & $4(1.9 \%)$ \\
Diarrhoea $(n=7)$ & $4(1.9 \%)$ \\
Ascites $(n=5)$ & $3(1.4 \%)$ \\
Splenomegaly $(n=5)$ & $1(0.5 \%)$ \\
Deterioration of general condition $(n=5)$ & 0 \\
Cutaneous eruption $(n=1)$ & 0 \\
\hline Percentags $n$ & \\
\hline
\end{tabular}

Percentages of total of positive IgM (213)

was observed in most patients (93.4\%), followed by vomiting (50.7\%), hepatalgia (47.4\%), asthenia $(26.8 \%)$ and physical signs like hepatomegaly (30.9\%) and distended abdomen (14.5\%).

To determine how long the infection persisted in the population, variations in IgM HEV positivity were monitored for 16 months, from June 2004, 1 month after the beginning of the outbreak, to September 2005 (Figure 1). The number of cases with IgM-HEV peaked in July 2004, September 2004 and March 2005. Between October 2004 and February 2005, between the two outbreaks, the level of infection remained constant at the background level.

In order to define the HEV-infected area, we collected blood and stools in different health care centres in the eight districts of Bangui, each of which has at least one public health care centre. As shown in Figure 2, IgMHEV was detected in patients from almost all districts of Bangui; however, more patients in the fourth and seventh districts presented for medical examination, and

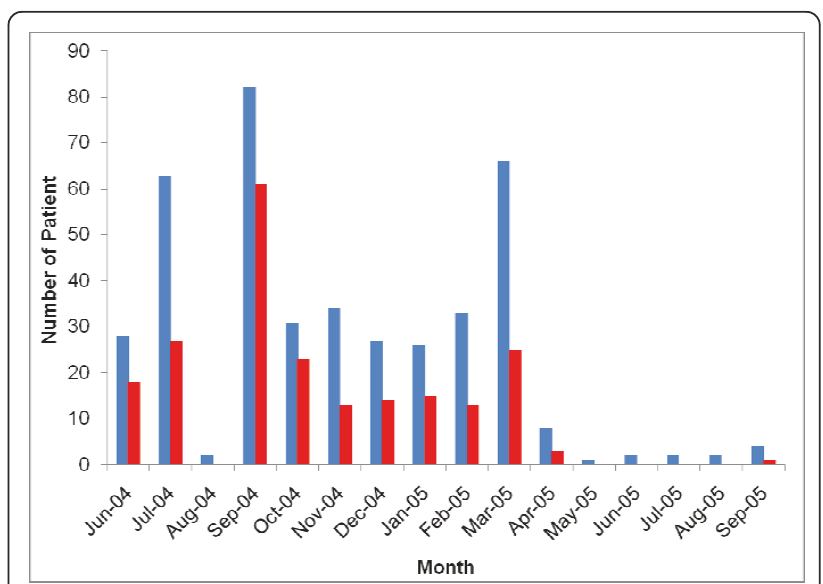

Figure 1 Evolution of IgM-HEV serology during 16 months, between June 2004 and the beginning of the outbreak to September 2005. Blue represents the total numbers of patients; red shows the number with detected IgM-HEV.

higher percentages of HEV infection were found in the seventh and eighth districts.

\section{Discussion}

During the 2004 outbreak of hepatitis E, more than 51\% of patients were infected with HEV. The most frequent clinical and biological signs were jaundice, vomiting, hepatalgia, hepatomegaly, asthenia, distended abdomen, fever and high levels of transaminases. A possible limitation of this study is the wide inclusion criteria, as physicians at the health care centres could include all patients who presented with jaundice or uncomplicated malaria. It is possible that this inclusion criterion biased our

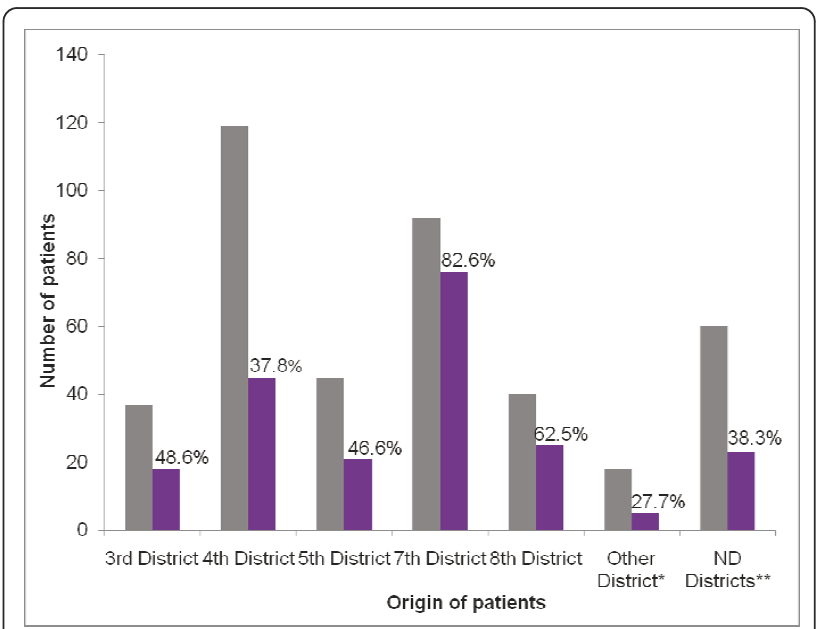

Figure 2 Locations of patients with positive IgM-HEV in Bangui and suburbs. Black represents the total number of patients; purple shows the number of patients who were IgM-HEV antibody-positive. Patients were from all eight districts of Bangui. *Other districts: first, second and third districts **ND district: district not determined. 
study, because other patients might not have been included or did not enter the defined categories. Nevertheless, the rate of IgM-HEV obtained was very high and was in accordance with that previously reported; e.g. $42 \%$ of patients were infected at the time of an epidemic of hepatitis E in Namibia [14].

The high prevalence of jaundice among our patients may be explained by the fact that CAR patients are more aware of this sign, because it is usually related to yellow fever and thus requires urgent medical examination. A study conducted in Pakistan [27] also showed that jaundice was present in almost all patients with HEV IgM positive serology. This sign was also found in 10 IgMHEV-positive patients in Nigeria [28]. Our study shows, however, that the presence of jaundice cannot confirm HEV infection, and vomiting, hepatalgia, asthenia, fever, elevated ALT levels and hepatomegaly, distended abdomen and fever must also be present [29]. As previously reported [30], we also found that adolescents and young adults were preferentially infected by HEV during the epidemic. This observation suggests that active people are more readily in contact with the virus, especially in tropical developing countries. In these countries, many people are farmers, who may be a source of contamination by HEV, because poultry and swine farmers, other professionals with an occupational activity related to farming and veterinarians are occupational risk groups and are more heavily exposed to HEV than other professions [31-35].

Biochemical determination of hepatic cytolysis by the detection of high levels of transaminases is an important parameter in the control of liver disease. In our study, the level of transaminases was four to five times higher than normal in more than three quarters of the infected patients. This confirms the presence of hepatic cytolysis, which usually accompanies infection with hepatitis viruses [36]. RT-PCR was not positive in all cases with IgM HEV, confirming that detection of the viral genome is generally difficult after the beginning of symptoms during epidemics of hepatitis E [37]. Our results could not formally link HEV infection to transaminases, because of the prevalence of many other infectious diseases, including other types of hepatitis, yellow fever and malaria, which may also increase hepatic enzymes [38].

The main inclusions occurred in July and September 2004 and March 2005, which correspond to the peaks of infection and were linked to positive IgM-HEV serology. In Bangui, the rainy season starts in May and finishes in December, and a recrudescence of cases of acute hepatitis $E$ is observed during that period in tropical countries, due to overflowing drains and short-circuiting of networks of clean water and structures for purifying wastewater. The level of endemicity results in high IgG anti-
HEV seroprevalences. As there is generally a single source of contamination, generally from water, epidemics of hepatitis $E$ are characterized by spectacular numbers of infected people $[37,39,40]$. The lack of samples during August was probably related to the absence of health professionals, who take their annual vacation at this time. The outbreak may therefore have peaked during August, and the peak observed in September might be only the downward part of the curve of infection. The period between October 2004 and February 2005 represents the inter-epidemic season. Asymptomatic excretion of HEV particles in the stools and the environmental reservoir of the HEV may explain the background noise observed and circulation of the virus.

Most patients came from the fourth and seventh districts of Bangui, but more cases of HEV infection were detected in patients living in the seventh and eighth districts. As the disease is related to exposure to faeces, hepatitis $\mathrm{E}$ is endemo-epidemic in areas where collective hygiene is badly monitored [3]. During epidemics, ingestion of viral particles by consumption of contaminated water is the principal mode of transmission, and more rarely by food soiled by human excreta. The seventh and eighth districts often have problems of overflowing drains and short-circuiting of networks of clean water and of structures to purify wastewater. Latrines are built close to wells, and water is usually used without treatment. All these insalubrities might explain the presence of the virus and the high rate of infection of the population in these two districts. Further, larger studies are necessary to determine the distribution of HEV in the districts of Bangui and to investigate the sources of the frequent outbreaks of HEV in this city since the first outbreak described in the suburbs in 2001 [25,26].

\section{Conclusion}

This study shows that there are no specific clinical or physical symptoms that might allow clinicians to diagnose hepatitis E. The clinical signs, dominated by jaundice, vomiting, hepatalgia and asthenia, are not specific to HEV infection, but could orient the clinician in the event of an association with an evocative epidemiological context. In order to avoid repetitive outbreaks and epidemics of hepatitis $\mathrm{E}$ in Bangui, it would be desirable to reinforce the preventive measures of individual and collective hygiene and to set up a monitoring system for this pathology.

\footnotetext{
Abbreviations

ALT: Alanine aminotransferase; AST: aspartate aminotransferase; CAR: Central African Republic; CDC: Centers for Disease Control and Prevention; HEV:

hepatitis E virus; IgM: immunoglobulin class M; lgG: immunoglobulin class G; RNA: ribonucleic acid; RT-PCR: reverse transcriptase polymerase chain reaction assay; USA: United States of America; WHO: World Health Organization.
} 


\section{Acknowledgements}

The authors wish to thank Dr Elisabeth Heseltine, Dr Mirdad Kazanji and all the scientific team of the Institut Pasteur de Bangui for participating in critical reading of the manuscript, and Dr Elisabeth Heseltine for her help in revising the written English. We are also thankful to Dr Alexandre Manirakiza for his help in the statistical analysis; to the Hôpital Communautaire, Hôpital de l'Amitié, Centre de Santé Saint Paul, Centre de Santé de Ouango, Centre de Santé Saint Paul, Centre de Santé de Gobongo, Centre de Santé de BoyRabe, Centre de Santé de Begoua, Centre de Santé de Bimbo, Centre de Santé de Petevo and Centre de Santé de Cattin for their help in collecting blood samples. Financial assistance from the Institut Pasteur de Bangui is gratefully acknowledged.

\section{Authors' contributions}

AIG, an MD in training at Institut Pasteur de Bangui, participated in the design of the study, examined the patients and also participated in interpretation of the data; XK carried out the immunoassays; NPK conceived of and designed the study, directed its implementation, interpreted data and drafted the manuscript. All authors read and approved the final manuscript.

\section{Competing interests}

The authors declare that they have no competing interests.

Received: 4 November 2010 Accepted: 14 April 2011

Published: 14 April 2011

\section{References}

1. Purcell RH, Emerson SU: Hepatitis E: an emerging awareness of an old disease. J Hepatol 2008, 48:494-503.

2. Okamoto H: Genetic variability and evolution of hepatitis E virus. Virus Res 2007, 127:216-228.

3. Mushahwar IK: Hepatitis E virus: molecular virology, clinical features, diagnosis, transmission, epidemiology, and prevention. J Med Virol 2008, 80:646-658.

4. Tei S, Kitajima N, Takahashi K, Mishiro S: Zoonotic transmission of hepatitis E virus from deer to human beings. Lancet 2003, 362:371-373.

5. Shukla P, Chauhan UK, Naik S, Anderson D, Aggarwal R: Hepatitis E virus infection among animals in northen India: an unlikely source of human disease. J Viral Hepat 2007, 14:310-317.

6. Ducancelle A, Payan C, Nicand E, Le Guillou H, Calès P, Lunel-Fabiani F: Intrafamilial hepatitis E in France. J Clin Virol 2007, 39:51-53.

7. Norder H, Sundqvist L, Magnusson L, Østergaard Breum S, Löfdahl M, Larsen LE, Hjulsager CK, Magnius L, Böttiger BE, Widén F: Endemic hepatitis $E$ in two Nordic countries. Euro Surveill 2009, 19: 14.

8. Haagsma EB, van den Berg AP, Porte RJ, Benne CA, Vennema H, Reimerink JH, Koopmans MP: Chronic hepatitis E virus infection in liver transplant recepients. Liver Transp/ 2008, 14:547-553.

9. Kamar N, Mansuy JM, Cointault O, Selves J, Abravanel F, Danjoux M, Otal P, Esposito L, Durand D, Izopet J, Rostaing L: Hepatitis E virus-related cirrhosis in kidney- and kidney-pancreas-transplant recipients. Am $J$ Transplant 2008, 8:1744-1748.

10. Kamar N, Selves J, Mansuy JM, Ouezzani L, Peron JM, Guitard J, Cointault O, Esposito L, Abravanel F, Danjoux M, Durand D, Vinel JP, Izopet J, Rostaing L: Hepatitis E virus and chronic hepatitis in organ-transplant recipients. N Engl J Med 2008, 358:811-817.

11. Jilani N, Das BC, Husain SA, Baweja UK, Chattopadhya D, Gupta RK, Sardan S, Kar P: Hepatitis E virus infection and fulminant hepatic failure during pregnancy. J Gastroenterol Hepatol 2007, 22:676-682.

12. Coursaget P, Buisson Y, N'Gawara MN, van Cuyck-Gandre H, Roue R: Role of hepatitis $\mathrm{E}$ virus in sporadic cases of acute and fulminant hepatitis in an endemic area (Chad). Am J Trop Med Hyg 1998, 58:330-334.

13. Fix AD, Abdel-Hamid M, Purcell RH, Shehata M, Abdel-Aziz F, Mikhail N, Sebai H, Nafeh M, Habib M, Arthur RR, Emerson SU, Strickland GT: Prevalence of antibodies to hepatitis $\mathrm{E}$ in two rural Egyptian communities. Am J Trop Med Hyg 2000, 62:519-523.

14. Isaacson M, Frean J, He J, Seriwatana J, Innis BL: An outbreak of hepatitis E in northern Namibia, 1983. Am J Trop Med Hyg 2000, 62:619-625.

15. Matsika-Claquin MD, Massanga M, Ménard D, Mazi-Nzapako J, Ténegbia JP, Mandeng MJ, Willybiro-Sacko J, Fontanet A, Talarmin A: HIV epidemic in
Central African Republic: high prevalence rates in both rural and urban areas. J Med Virol 2004, 72(3):358-62.

16. Komas NP, Baï-Sepou S, Manirakiza A, Léal J, Béré A, Le Faou A: The prevalence of hepatitis $B$ virus markers in a cohort of students in Bangui, Central African Republic. BMC Infect Dis 2010, 10:226.

17. Njouom R, Frost E, Deslandes S, Mamadou-Yaya F, Labbé AC, Pouillot $R$, Mbélesso P, Mbadingai S, Rousset D, Pépin J: Predominance of hepatitis $C$ virus genotype 4 infection and rapid transmission between 1935 and 1965 in the Central African Republic. J Gen Virol 2009, 90(Pt 10):2452-2456

18. Sall AA, Faye O, Diallo M, Firth C, Kitchen A, Holmes EC: Yellow fever virus exhibits slower evolutionary dynamics than dengue virus. J Virol 2010, 84(2):765-72.

19. Dolmazon V, Matsika-Claquin MD, Manirakiza A, Yapou F, Nambot M, Menard D: Genetic diversity and genotype multiplicity of Plasmodium falciparum infections in symptomatic individuals living in Bangui (CAR). Acta Trop 2008, 107(1):37-42.

20. Garin B, Glaziou P, Kassa-Kelembho E, Yassibanda S, Mbelesso P, Morvan J: High mortality rates among patients with tuberculosis in Bangui, Central African Republic. Lancet 1997, 350(9087):1298.

21. Kassa-Kelembho E, Mbolidi CD, Service YB, Morvan J, Minssart P: Bacteremia in adults admitted to the Department of Medicine of Bangui Community Hospital (Central African Republic). Acta Trop 2003, 89(1):67-72.

22. Judde JG, Lacoste V, Brière J, Kassa-Kelembho E, Clyti E, Couppié $P$, Buchrieser C, Tulliez M, Morvan J, Gessain A: Monoclonality or oligoclonality of human herpesvirus 8 terminal repeat sequences in Kaposi's sarcoma and other diseases. J Natl Cancer Inst 2000, 92(9):729-36.

23. Smith DH, Pepin J, Stich AH: Human African trypanosomiasis: an emerging public health crisis. Br Med Bull 1998, 54(2):341-55

24. Pawlotsky JM, Bélec L, Grésenguet $G$, Deforges $L$, Bouvier M, Duval J, Dhumeaux D: High prevalence of hepatitis B, C, and E markers in young sexually active adults from the Central African Republic. J Med Virol 1995, 46:269-273.

25. Goumba CM, Yandoko-Nakouné ER, Komas NP: A fatal case of acute hepatitis $\mathrm{E}$ among pregnant women, Central African Republic. BMC Res Notes 2010, 3:103.

26. Escriba JM, Nakouné E, Recio C, Massamba PM, Matsika-Claquin MD, Goumba C, Rose AM, Nicand E, Garcia E, Leklegban C, Koffi B: Hepatitis E, Central African Republic. Emerg Infect Dis 2008, 14:681-683.

27. Saeddi Ml, Mahmood K, Amanullah, Ziauddin M, llyas N, Zarif M: Frequency and clinical course of hepatitis E in tertiary care hospitals. $J$ Coll Physicians Surg Pak 2004, 14:527-529.

28. Buisson Y, Grandadam M, Nicand E, Cheval P, van Cuyck-Gandre H, Innis B, Rehel P, Coursaget P, Teyssou R, Tsarev S: Identification of a novel hepatitis E virus in Nigeria. J Gen Virol 2000, 81(Pt4):903-909.

29. Smith JL: A review of hepatitis E virus. J Food Prot 2001, 64:572-586.

30. Chandra V, Taneja S, Kalia M, Jameel S: Molecular biology and pathogenesis of hepatitis E virus. J Biosci 2008, 33:451-464.

31. Lewis HC, Wichmann O, Duizer E: Transmission routes and risk factors for autochthonous hepatitis E virus infection in Europe: a systematic review. Epidemiol Infect 2010, 138:145-166.

32. Pourpongporn P, Samransurp K, Rojanasang P, Wiwattanakul S, Srisurapanon S: The prevalence of anti-hepatitis $\mathrm{E}$ in occupational risk groups. J Med Ass Thai 2009, 92(Suppl3):S38-S42.

33. Christensen PB, Engle RE, Hjort C, Homburg KM, Vach W, Georgsen J, Purcell RH: Time trend of the prevalence of hepatitis $E$ antibodies among farmers and blood donors: a potential zoonosis in Denmark. Clin Infect Dis 2008, 47:1026-1031.

34. Olsen B, Axelsson-Olsson D, Thelin A, Weiland O: Unexpected high prevalence of IgG-antibodies to hepatitis E virus in Swedish pig farmers and controls. Scand J Infect Dis 2006, 38:55-58.

35. Meng XJ, Wiseman B, Elvinger F, Guenette DK, Toth TE, Engle RE, Emerson SU, Purcell RH: Prevalence of antibodies to hepatitis E virus in veterinarians working with swine and in normal blood donors in the United States and other countries. J Clin Microbiol 2002, 40:117-122.

36. Panda SK, Thakral D, Rehman S: Hepatitis E virus. Rev Med Virol 2007, 17:151-180

37. Chandra NS, Sharma A, Malhotra B, Rai RR: Dynamics of HEV viremia, fecal shedding and its relationship with transaminases and antibody response in patients with sporadic acute hepatitis E. Virol I 2010, 7:213. 
38. Khuroo MS, Khuroo MS: Hepatitis E virus. Curr Opin Infect Dis 2008, 21:539-543.

39. Mushahwar IK, Dawson GJ, Bile KM, Magnius LO: Serological studies of an enterically transmitted non-A non-B hepatitis in Somalia. J Med Virol 1993, 40:218-221.

40. Bile KM, Isse A, Mohamud O, Allebeck P, Nilsson L, Norder H, Mushahwar IK, Magnius LO: Contrasting roles of rivers and wells as sources of drinking water on attack and fatality rates in a hepatitis E epidemic in Somalia. Am J Trop Med Hyg 1994, 51:466-474.

\section{Pre-publication history}

The pre-publication history for this paper can be accessed here: http://www.biomedcentral.com/1471-2334/11/93/prepub

doi:10.1186/1471-2334-11-93

Cite this article as: Goumba et al:: Clinical and epidemiological aspects of a hepatitis E outbreak in Bangui, Central African Republic. BMC Infectious Diseases 2011 11:93.

\section{Submit your next manuscript to BioMed Central} and take full advantage of:

- Convenient online submission

- Thorough peer review

- No space constraints or color figure charges

- Immediate publication on acceptance

- Inclusion in PubMed, CAS, Scopus and Google Scholar

- Research which is freely available for redistribution

Submit your manuscript at www.biomedcentral.com/submit 